\title{
Article \\ Molecular Detection of Toxigenic Clostridioides difficile among Diarrheic Dogs and Cats: A Mounting Public Health Concern
}

\author{
Ahmed Samir ${ }^{1}$, Khaled A. Abdel-Moein ${ }^{2}$ and Hala M. Zaher ${ }^{2, *}$ \\ 1 Department of Microbiology, Faculty of Veterinary Medicine, Cairo University, Cairo 12211, Egypt; \\ ahmed.samir@cu.edu.eg \\ 2 Department of Zoonoses, Faculty of Veterinary Medicine, Cairo University, Cairo 12211, Egypt; \\ khal_105@cu.edu.eg \\ * Correspondence: drhalazaher@cu.edu.eg; Tel.: +20-100-230-8393; Fax: +20-23-572-5240
}

check for updates

Citation: Samir, A.; Abdel-Moein, K.A.; Zaher, H.M. Molecular Detection of Toxigenic Clostridioides difficile among Diarrheic Dogs and Cats: A Mounting Public Health Concern. Vet. Sci. 2021, 8, 88 . https://doi.org/10.3390/vetsci8060088

Academic Editor: Enrico Gugliandolo

Received: 7 April 2021

Accepted: 19 May 2021

Published: 22 May 2021

Publisher's Note: MDPI stays neutral with regard to jurisdictional claims in published maps and institutional affiliations.

Copyright: (c) 2021 by the authors. Licensee MDPI, Basel, Switzerland. This article is an open access article distributed under the terms and conditions of the Creative Commons Attribution (CC BY) license (https:// creativecommons.org/licenses/by/ $4.0 /)$.

\begin{abstract}
Nowadays, pet animals are known to be asymptomatic carriers of Clostridioides difficile. This study was conducted to investigate the burden of toxigenic $C$. difficile among diarrheic dogs and cats using direct PCR on fecal samples to reveal better insights about the epidemiology of such toxigenic strains referring to its public health significance. For this purpose, fecal samples were obtained from 58 dogs and 42 cats experiencing diarrhea. Following DNA extraction, the extracted DNA was examined for the occurrence of $C$. difficile as well as toxigenic strains through the detection of $C$. difficile $16 \mathrm{~S}$ rRNA and toxin encoding genes $(t c d A, t c d B, c d t A$ and $c d t B)$ using PCR. Moreover, partial DNA sequencing of toxigenic strains retrieved from dog and cat was carried out. Of 100 examined diarrheic animals, 90 (90\%) were C. difficile positive, including $93.1 \%$ and $85.7 \%$ of dogs and cats, respectively. In addition, toxigenic strains were detected in 13 animals, giving an overall prevalence $13 \%$ with the following prevalence rates among dogs and cats $12.1 \%$ and $14.3 \%$, respectively. Furthermore, the phylogenetic analysis of the obtained sequence revealed high genetic relatedness of $t c d A$ sequence obtained from a cat to strains of human diarrheic cases to point out the public health threat of such sequence. In conclusion, the direct detection of toxigenic $C$. difficile using PCR among dogs and cats highlights the potential role of household pets as a source for such strains to human contacts.
\end{abstract}

Keywords: toxigenic C. difficile; dogs; cats; public health

\section{Introduction}

Clostridioides difficile (formerly known as Clostridium difficile) is an emerging enteric pathogen in human and veterinary medicine [1]. It is a Gram-positive, strictly anaerobic, spore forming toxin-mediated bacillus [2]. In the last four decades, after admission of broad-spectrum antibiotics, the role of $C$. difficile in enteric diseases began to flare up to become a remarkable cause of nosocomial associated diarrhea and pseudomembranous colitis among human being [3]. However, nowadays, there is increasing number of $C$. difficile infection (CDI) cases outside health care settings referring to community acquired CDI, which accounts for one quarter of all reported CDI cases [4,5]. Nonetheless, there is no definitive source of CDI in the community settings [6] and this has urged researchers to investigate the potential role of animals as a vector for transmission of CDI [4]. Notably, this pathogen has been implicated in gastrointestinal diseases among diverse animal species, including food producing animals as well as companion animals [7-11]. Regarding pet animals, there were a lot of reports investigated $C$. difficile in dogs with gastrointestinal disorders [12-15] while in cats, little is known concerning association between $C$. difficile and feline enteric diseases [16,17]. The characteristic diarrhea and gastrointestinal tract inflammation in pet animals and humans are mainly attributed to toxin producing $C$. difficile $[18,19]$. Basically, pathogenic C. difficile strains produce two main toxins: toxin A and toxin $B$ which encoded by $t c d A$ and $t c d B$ genes, respectively [20] with some strains 
producing a binary toxin $C$. difficile transferase (CDT) [21]. While toxin A is an enterotoxin causing severe gut inflammation, toxin B is a potent cytotoxin that is responsible for cellular death and damage of epithelial tissue [22]. Investigation of $C$. difficile and its toxins in diarrheic animals relies on conventional methods such as culture may yield underestimated results $[13,23]$. Recently, direct detection of $C$. difficile in animal fecal samples using PCR was found to give significantly higher detection rate rather than conventional culture technique [24] whereas, the direct detection of toxin encoding genes is a reliable tool for the detection of toxigenic strains [25]. Accordingly, the current study was carried out to investigate the occurrence of toxigenic $C$. difficile via direct PCR on feces of pet animals suffering from diarrhea to give insight about the burden of toxigenic C. difficile strains among diarrheic pet animals for better understanding the epidemiology of such strains referring to its public health implication.

\section{Materials and Methods}

\subsection{Ethical Statement}

The protocol of this study was approved by ethical committee of Faculty of Veterinary Medicine, Cairo University, Egypt with an ethical approval code: Vet CU28/04/2021/321.

\subsection{Sample Collection}

Fecal samples were obtained from 100 diarrheic pet animals (58 dogs and 42 cats) from private veterinary clinics where animals of different ages were included in this study. These samples were collected in sterile cups, transported in an icebox to the laboratory and stored at $-20{ }^{\circ} \mathrm{C}$ for further processing.

\subsection{Molecular Investigation of $\mathrm{C}$. difficile and Toxin Encoding Genes}

\subsubsection{DNA Extraction}

DNA was extracted from each fecal sample using FavorPrep ${ }^{\text {TM }}$ Stool DNA Isolation Mini Kit (Favorgen, Taiwan, Cat No. FASTI 001-1) according to the manufacturer protocol. Then after, the extracted DNA was stored at $-20^{\circ} \mathrm{C}$ till further molecular analysis.

\subsubsection{Direct Detection of $C$. difficile}

The extracted DNA was screened for the presence of $C$. difficile via direct detection of C. difficile 16S rRNA using the following primers: B (CCGTCAATTCMTTTRAGTTT) and PG-48 (CTCTTGAAACTGGGAGACTTGA) (Metabion, Steinkirchen, Germany) [26]. The PCR reaction was carried out in a final volume $25 \mu \mathrm{L}$ where $3 \mu \mathrm{L}$ of DNA template, $1 \mu \mathrm{L}$ of each primer, $12.5 \mu \mathrm{L}$ of Cosmo PCR red master mix (Willowfort, Birmingham, UK, Cat No. WF10203001) and 7.5 $\mu \mathrm{L}$ of nuclease free water were included in each reaction. The thermal profile of PCR reaction was as follows: Initial denaturation at $95^{\circ} \mathrm{C}$ for $3 \mathrm{~min}$ followed by 40 cycles of denaturation at $95{ }^{\circ} \mathrm{C}$ for $30 \mathrm{~s}$, annealing at $44^{\circ} \mathrm{C}$ for $30 \mathrm{~s}$, extension at $72{ }^{\circ} \mathrm{C}$ for $30 \mathrm{~s}$ then final extension at $72{ }^{\circ} \mathrm{C}$ for $5 \mathrm{~min}$. Afterwards, amplicons were analyzed with agarose gel electrophoresis (BioRad, Hercules, USA) and photographed to yield specific band at $270 \mathrm{bp}$ (Figure 1).

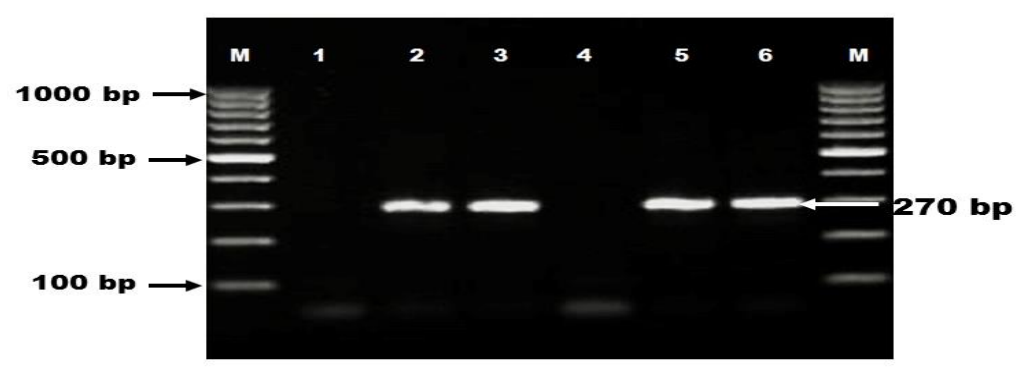

Figure 1. Occurrence of $C$. difficile $16 \mathrm{~S}$ rRNA among diarrheic dogs and cats. Lane M: DNA ladder (100 bp); lane 1: negative control; lanes 2, 3, 5, 6: positive samples with specific band at $270 \mathrm{bp}$; lane 4: negative sample. 


\subsubsection{Direct Detection of $C$. difficile Toxin Genes}

$t c d A$ and $t c d B$ Genes

Investigation of $C$. difficile $t c d A$ and $t c d B$ genes encoding toxin $A$ and toxin $B$, respectively was carried out in all animals. Primers designed to amplify regions of $t c d A$ and $t c d B$ were as follow: $t c d A$ (YT-28 GCATGATAAGGCAACTTCAGTGG and YT-29 GAGTAAGTTCCTCCTGCTCCATCAA), $t c d B$ (YT-17 GGTGGAGCTGCTTCATTGGAGAG and YT-18 GTGTAACCTACTTTCATAACACCA) (Metabion, Steinkirchen, Germany) [27]. The PCR assay was done at $95{ }^{\circ} \mathrm{C}$ for 3 min then 40 cycles of denaturation $\left(95^{\circ} \mathrm{C}\right.$ for $\left.20 \mathrm{~s}\right)$, annealing $\left(53^{\circ} \mathrm{C}, 49^{\circ} \mathrm{C}\right.$ for $t c d A$ and $t c d B$ respectively for $\left.25 \mathrm{~s}\right)$, extension $\left(72{ }^{\circ} \mathrm{C}\right.$ for $\left.1 \mathrm{~min}\right)$ followed by final extension at $72{ }^{\circ} \mathrm{C}$ for $7 \mathrm{~min}$. The PCR products were observed under UV transilluminator (BioRad, Hercules, CA, USA) after electrophoresis step in 1.5\% agarose gel (Sigma-Aldrich, Saint Louis, USA, Cat No. A0576) stained with $0.5 \mu \mathrm{g} / \mathrm{mL}$ of ethidium bromide (Sigma-Aldrich, Saint Louis, USA, Cat No. E7637) as specific band of $t c d A$ gene was showed at $602 \mathrm{bp}$ (Figure 2).

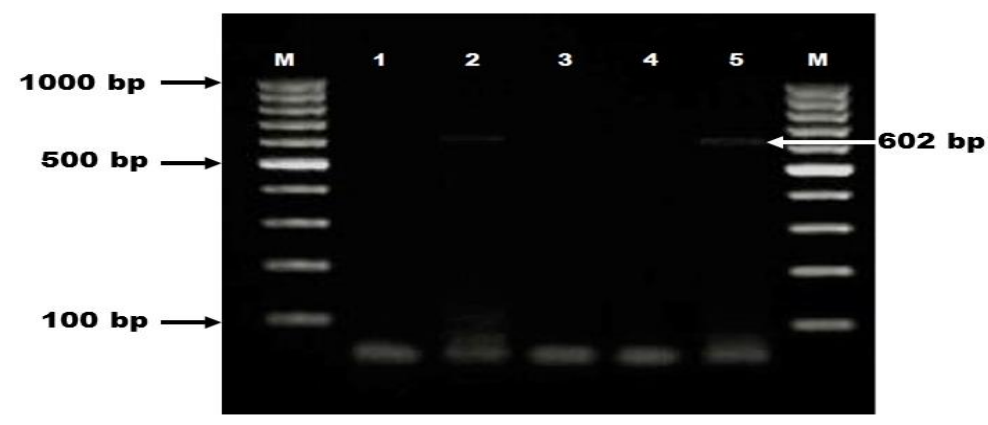

Figure 2. Molecular detection of $C$. difficile tcdA gene among diarrheic dogs and cats. Lane M: DNA ladder (100 bp); lane 1: negative control; lanes 2,5: positive samples showed specific band at $602 \mathrm{bp}$; lanes 3,4: negative samples.

$c d t A$ and $c d t B$ Genes

The multiplex PCR amplification for binary toxin genes $(c d t A$ and $c d t B)$ was carried out as follows: after 4 min of initial denaturation at $94{ }^{\circ} \mathrm{C}, 30$ cycles of $94{ }^{\circ} \mathrm{C}$ for $45 \mathrm{~s}, 52^{\circ} \mathrm{C}$ for $1 \mathrm{~min}$ and $72{ }^{\circ} \mathrm{C}$ for $80 \mathrm{~s}$ were conducted then followed by $72{ }^{\circ} \mathrm{C}$ for $5 \min$ [28].

\subsubsection{Partial DNA Sequencing of $C$. difficile $t c d A$ and $t c d B$ Genes}

One PCR product of toxin A obtained from a cat and another one of toxin $B$ retrieved from a dog were purified via a QIAquick purification kit (Qiagen, Hilden, Germany, Cat No. 28104) then they were subjected for sequencing using Big Dye Terminator V3.1 kit (Thermo Fisher, Waltham, MA, USA, Cat No. 4337455) in ABI 3500 Genetic Analyzer (Applied Biosystems, Foster City, CA, USA).

\subsection{Nucleotide Sequence Accession Numbers}

Partial sequences of $C$. difficile $t c d A$ and $t c d B$ genes were submitted to GenBank and deposited in GenBank database with the following accession numbers: MW340088 for $t c d A$ and MW357902 for $t c d B$.

\subsection{Sequence Identity BLAST Analysis}

The obtained $t c d A$ and $t c d B$ sequences from cat and dog respectively, were compared with C. difficile strains available on GenBank using NCBI website via BLAST analysis to display the identity percentage between our sequences and those of human clinical cases from different countries to clarify the public health significance of such strains. 


\subsection{Phylogenetic Analysis}

The recovered $t c d A$ cat strain was aligned against similar $C$. difficile toxin A sequences retrieved from animals as well as strains obtained from human clinical cases worldwide to confer the genetic relatedness between pets and human strains to understand the public health implications of our findings. Clustal W multiple alignment was conducted using Bioedit software version 7.0.9 while MEGA 7 software was used to construct phylogenetic tree via neighbor-joining approach where bootstrap consensus tree was obtained with 500 replicates (Figure 3).

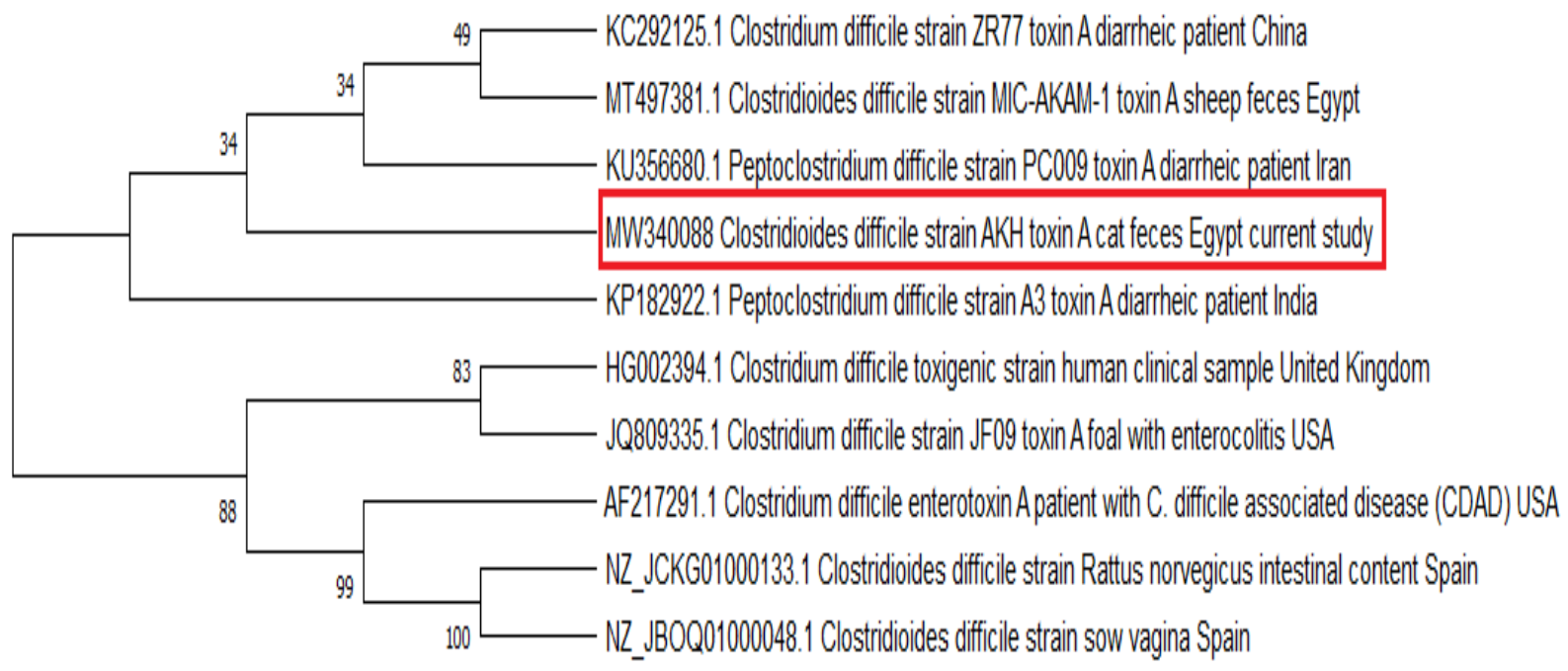

Figure 3. Phylogenetic consensus tree was constructed using neighbor-joining approach via Mega 7 software to display the genetic relatedness between $t c d A$ sequence obtained from a cat and those retrieved from Genbank.

\subsection{Statistical Analysis}

The influence of age on prevalence rate of toxigenic $C$. difficile was analyzed by SPSS software version 18.0 using chi square $(\chi 2)$ test. The result was considered statistically significant when $p$-value was less than 0.05 .

\section{Results}

Of 100 examined diarrheic animals, $90(90 \%)$ were C. difficile positive, including $93.1 \%$ and $85.7 \%$ of dogs and cats, respectively. For toxigenic C. difficile, $13(13 \%)$ out of 100 animals had $C$. difficile toxins comprising $12.1 \%(7 / 58)$ and $14.3 \%(6 / 42)$ of dogs and cats, respectively. Moreover, according to toxin production type, 4 dogs and 4 cats were positive for $t c d A$ and negative for $t c d B$ while one dog and two cats carried toxin $B$ and negative for toxin $A$ as well as both $t c d A$ and $t c d B$ genes had been detected in two dogs. On the other hand, none of binary toxins ( $c d t A$ and $c d t B$ ) was found among the examined dogs and cats as shown in Table 1. Regarding animal age, the prevalence of toxigenic $C$. difficile was as follows: $14 \%$ (less than 6 months), $14.8 \%$ (6-12 months) and 16.7\% (greater than 12 months) (Table 2). Statistically, no significant relationship ( $p$ value $=0.94$ ) was observed between toxigenic $C$. difficile and animal age. The similarity ratios between the obtained C. difficile $t c d A$ and $t c d B$ sequences in this study and those of public health importance according to the BLAST analysis were displayed in Table 3. 
Table 1. Occurrence of $C$. difficile $16 \mathrm{~S}$ rRNA and toxin encoding genes among diarrheic dogs and cats.

\begin{tabular}{|c|c|c|c|c|c|c|c|}
\hline $\begin{array}{l}\text { Animal } \\
\text { Species }\end{array}$ & $\begin{array}{l}\text { No. of Examined } \\
\text { Animals }\end{array}$ & & $\begin{array}{l}\text { No. of Positive } \\
\text { Animals (\%) }\end{array}$ & & & & \\
\hline & & $\begin{array}{l}\text { C. difficile } 16 \mathrm{~S} \\
\text { rRNA }\end{array}$ & & $\begin{array}{c}\text { Toxigenic C. } \\
\text { difficile }\end{array}$ & & & \\
\hline & & & $t c d A+t c d B-$ & $t c d A-t c d B+$ & $t c d A+t c d B+$ & Binary Toxins (CDT) & Total \\
\hline Dogs & 58 & $54(93.1)$ & $4(6.9)$ & $1(1.7)$ & $2(3.4)$ & $0(0)$ & 7 (12.1) \\
\hline Cats & 42 & $36(85.7)$ & $4(9.5)$ & $2(4.8)$ & $0(0)$ & $0(0)$ & $6(14.3)$ \\
\hline Total & 100 & $90(90)$ & $8(8)$ & $3(3)$ & $2(2)$ & $0(0)$ & 13 (13) \\
\hline
\end{tabular}

Table 2. Occurrence of toxigenic $C$. difficile among pet animals of different ages.

\begin{tabular}{cccc}
\hline Age of Animals & No. of Examined Animals & Positive Animals & \\
\hline & & No. & \\
\hline$<6 \mathrm{M}$ & 43 & 6 & 14 \\
$6-12 \mathrm{M}$ & 27 & 4 & 14.8 \\
$>12 \mathrm{M}$ & 30 & 5 & 16.7 \\
Total & 100 & 15 & 15 \\
\hline
\end{tabular}

Table 3. The identity percentage of obtained C. difficile $t c d A$ and $t c d B$ partial sequences in this study with $C$. difficile strains deposited in Genbank of public health significance.

\begin{tabular}{ccccc}
\hline Sequence & Genbank ID & Isolation Source & Country & \% Identity \\
\hline $\begin{array}{c}\text { MW340088 } \\
(t c d A \text { cat sequence })\end{array}$ & KP182922.1 & Diarrheic patient & India & 100 \\
\hline & CP022524.1 & Hospitalized pediatric patient with diarrhea & USA & 99.81 \\
\hline & CP010905.2 & Patient with severe pseudomembranous colitis & Switzerland & China \\
\hline & KC292061.1 & Diarrheic patient & France & 99.81 \\
\hline $\begin{array}{c}\text { MW357902 } \\
(t c d B \text { dog sequence })\end{array}$ & DQ117266.1 & Patient with antibiotic associated diarrhea & China \\
\hline & KC292138.1 & Diarrheic patient & 99.72 \\
\hline & CP010905.2 & Patient with severe pseudomembranous colitis & Switzerland & 99.48 \\
\hline & DQ117268.1 & Patient with pseudomembranous colitis & France & 99.43 \\
\hline
\end{tabular}

\section{Discussion}

In the last few years, pet dogs and cats were found to be potential reservoirs for some emerging nosocomial pathogens with great public health concern $[29,30]$. Such previous studies have paved the way for more investigations about the role of pet animals in the epidemiology of other nosocomial pathogens likewise $C$. difficile and nowadays, the implication of household pets in community acquired CDI is an ongoing public health issue [6]. In the current study, C. difficile was detected in $90 \%$ of diarrheic pet animals where $93.1 \%$ and $85.7 \%$ of dogs and cats were positive, respectively. Our results were higher than those reported in previous studies 6.7\% [15], 25\% [31] for dogs and 12.9\% [17], $15.7 \%$ [31] for cats suffering from diarrhea. Such high unexpected results in the current study may be owed to the direct detection of $C$. difficile by PCR using $16 \mathrm{~S}$ rRNA primers can detect as little as 10 cells of $C$. difficile among $10^{10}-10^{11}$ total bacterial cells per one gram of stool [32]. On the contrary, other studies recovered C. difficile via conventional culture technique which needs at least $1000 \mathrm{cfu} /$ gram of feces on the selective $C$. difficile culture media to yield successful cultivation. Therefore, the direct detection of $C$. difficile by PCR can elucidate the burden of CDI among diarrheic pet animals and consequently triggers a growing public health concern. 
Regarding toxigenic $C$. difficile, 13 out of 100 diarrheic pet animals were positive for toxin encoding genes, whereas $12.1 \%(7 / 58)$ of investigated dogs carried $C$. difficile toxins. Our finding was lower than that reported by Weese et al. [12] who found $21 \%(18 / 87)$ of examined diarrheic dogs were toxigenic using an ELISA assay. While in cats, the prevalence of toxigenic $C$. difficile was $14.3 \%(6 / 42)$. Such result was higher than that reported by Silva et al. [17] who detected toxigenic $C$. difficile in $3(4.3 \%)$ out of 70 diarrheic cats by PCR carried out on recovered $C$. difficile isolates.

From a public health point of view, $C$. difficile associated diarrhea in human being is mainly attributed to toxigenic strains [19]. Importantly, in the current study, there were two dogs carried both toxin $A$ and toxin $B$ which may refer to presence of $A+/ B+$ toxinotype. C. difficile $\mathrm{A}+/ \mathrm{B}+$ is the most predominant toxigenic strain isolated from diarrheic dogs in studies conducted by Wetterwik et al. [13], Andrés-Lasheras et al. [15], Ghavidel et al. [33] and Silva et al. [34]. Likewise, it is the most pathogenic C. difficile toxinotype in human being and is primarily accounted for $C$. difficile associated disease (CDAD) worldwide $[35,36]$. Moreover, there were one $\operatorname{dog}$ and two cats had $t c d B$ gene but negative for $t c d A$ which may indicate $A-/ B+$ strain. Such toxinotype has attracted the attention of researchers in recent years [37] because it has been incriminated in four nosocomial outbreaks of $C$. difficile associated diarrhea in Canada [38], Netherlands [39], Japan [40] and Dublin [41] as well as 4 dogs and 4 cats were found to be toxin A positive and toxin B negative; this strain also had been detected among diarrheic patients in intensive care unit [42]. On the other hand, all the examined dogs and cats were negative for binary toxin genes. In agreement with our result, Andrés-Lasheras et al. [15] and Silva et al. [17] who could not find binary toxins in C. difficile isolates recovered from diarrheic dogs and cats, respectively. Pet dogs and cats are in frequent and close contact with their owners and usually share the same places at home like living room and bedroom. Accordingly, diarrheic pet animals may be considered as a potential source for dissemination of toxigenic $C$. difficile strains within a community. Therefore, our findings indicate that the direct PCR detection of toxigenic C. difficile in feces of diarrheic dogs and cats can give a better insight to understand the epidemiology of toxigenic $C$. difficile infection among pet animals.

On the other hand, the prevalence of toxin producing $C$. difficile was found to be increased with age of pet animals as animals of age greater than 12 months had a higher percentage $(16.7 \%)$ but there was no significant relationship between age and prevalence rate of toxigenic C. difficile. Similarly, Álvarez-Pérez et al. [23] and Diniz et al. [43] reported that shedding of $C$. difficile and its toxins was increased with pet animals of higher ages.

Interestingly, in this study, we provide $C$. difficile $t c d A$ and $t c d B$ partial sequences from a cat and a dog, respectively, where cat and dog strains showed high identity percentage of $99.81 \%-100 \%$ and $99.43 \%-99.72 \%$ respectively to C. difficile isolates retrieved from patients with diarrhea and pseudomembranous colitis worldwide to highlight the public health impact of such strains. In the meantime, phylogenetic tree was constructed to encompass C. difficile toxin A sequences from animals as well as human strains including diarrheic patients from different countries (Figure 3). It was obvious that $t c d A$ sequence from a cat was grouped within the same cluster with that reported in sheep in the same country (Egypt) and those of human diarrheic cases originated from Asian countries (China, India, and Iran). Thus, the high genetic relatedness of our sequence to those of humans points out a potential relationship between cats and diarrheal infection in human being rendering pet animals a potential zoonotic source for toxigenic $C$. difficile human infection.

\section{Conclusions}

This study provides more knowledge regarding the epidemiology of toxigenic $C$. difficile infection among diarrheic dogs and cats. Remarkably, the direct detection of toxigenic $C$. difficile using PCR in animal samples opens a gate for better assessment of toxigenic CDI burden among household pets which subsequently, reflects on human health. 
Author Contributions: K.A.A.-M. and A.S.: Idea, study design, supervising the work and writing manuscript. H.M.Z.: Sample collection, molecular techniques and writing manuscript. All authors have read and agreed to the published version of the manuscript.

Funding: This research received no external funding.

Institutional Review Board Statement: The protocol of this study was approved by ethical committee of Faculty of Veterinary Medicine, Cairo University, Egypt with an ethical approval code: Vet CU28/04/2021/321.

Informed Consent Statement: Not applicable.

Data Availability Statement: Not applicable.

Conflicts of Interest: The authors declare no conflict of interest.

\section{References}

1. Keessen, E.C.; Gaastra, W.; Lipman, L.J. Clostridium difficile infection in humans and animals, differences and similarities. Vet. Microbiol. 2011, 153, 205-217. [CrossRef]

2. Zhu, D.; Sorg, J.A.; Sun, X. Clostridioides difficile Biology: Sporulation, Germination, and Corresponding Therapies for C. difficile Infection. Front. Cell Infect. Microbiol. 2018, 8, 29. [CrossRef] [PubMed]

3. Burnham, C.D.; Carroll, K.C. Diagnosis of Clostridium difficile Infection: An Ongoing Conundrum for Clinicians and for Clinical Laboratories. Clin. Microbiol. Rev. 2013, 26, 604-630. [CrossRef] [PubMed]

4. Hensgens, M.P.; Keessen, E.C.; Squire, M.M.; Riley, T.V.; Koene, M.G.; de Boer, E.; Lipman, L.J.; Kuijper, E.J.; European Society of Clinical Microbiology and Infectious Diseases Study Group for Clostridium difficile (ESGCD). Clostridium difficile infection in the community: A zoonotic disease? Clin. Microbiol. Infect. 2012, 18, 635-645. [CrossRef] [PubMed]

5. Gupta, A.; Khanna, S. Community-acquired Clostridium difficile infection: An increasing public health threat. Infect. Drug Resist. 2014, 7, 63-72. [PubMed]

6. Hernandez, B.G.; Vinithakumari, A.A.; Sponseller, B.; Tangudu, C.; Mooyottu, S. Prevalence, Colonization, Epidemiology, and Public Health Significance of Clostridioides difficile in Companion Animals. Front. Vet. Sci. 2020, 7, 512551. [CrossRef]

7. Kachrimanidou, M.; Tzika, E.; Filioussis, G. Clostridioides (Clostridium) Difficile in Food-Producing Animals, Horses and Household Pets: A Comprehensive Review. Microorganisms 2019, 7, 667. [CrossRef]

8. Hammitt, M.C.; Bueschel, D.M.; Keel, M.K.; Glock, R.D.; Cuneo, P.; DeYoung, D.W.; Reggiardo, C.; Trinh, H.T.; Songer, J.G. A possible role for Clostridium difficile in the etiology of calf enteritis. Vet. Microbiol. 2008, 127, 343-352. [CrossRef]

9. Avberšek, J.; Pirš, T.; Pate, M.; Rupnik, M.; Ocepek, M. Clostridium difficile in goats and sheep in Slovenia: Characterization of strains and evidence of age-related shedding. Anaerobe 2014, 28, 163-167. [CrossRef] [PubMed]

10. Weese, J.S.; Staempfli, H.R.; Prescott, J.F. A prospective study of the roles of Clostridium difficile and enterotoxigenic Clostridium perfringens in equine diarrhoea. Equine Vet. J. 2001, 33, 403-409. [CrossRef]

11. Weese, J.S.; Armstrong, J. Outbreak of Clostridium difficile-associated disease in a small animal veterinary teaching hospital. J. Vet. Intern Med. 2003, 17, 813-816. [PubMed]

12. Weese, J.S.; Staempfli, H.R.; Prescott, J.F.; Kruth, S.A.; Greenwood, S.J.; Weese, H.E. The roles of Clostridium difficile and enterotoxigenic Clostridium perfringens in diarrhea in dogs. J. Vet. Intern Med. 2001, 15, 374-378. [CrossRef]

13. Wetterwik, K.J.; Trowald-Wigh, G.; Fernström, L.L.; Krovacek, K. Clostridium difficile in faeces from healthy dogs and dogs with diarrhea. Acta Vet. Scand. 2013, 55, 23. [CrossRef]

14. Orden, C.; Blanco, J.L.; Álvarez-Pérez, S.; Garcia-Sancho, M.; Rodriguez-Franco, F.; Sainz, A.; Villaescusa, A.; Harmanus, C.; Kuijper, E.; Garcia, M.E. Isolation of Clostridium difficile from dogs with digestive disorders, including stable metronidazoleresistant strains. Anaerobe 2017, 43, 78-81. [CrossRef] [PubMed]

15. Andrés-Lasheras, S.; Martín-Burriel, I.; Mainar-Jaime, R.C.; Morales, M.; Kuijper, E.; Blanco, J.L.; Chirino-Trejo, M.; Bolea, R. Preliminary studies on isolates of Clostridium difficile from dogs and exotic pets. BMC Vet. Res. 2018, 14, 77. [CrossRef] [PubMed]

16. Weese, J.S. Clostridium (Clostridioides) difficile in animals. J. Vet. Diagn. Investig. 2020, 32, 213-221. [CrossRef] [PubMed]

17. Silva, R.O.S.; Ribeiro, M.G.; de Paula, C.L.; Pires, I.H.; Oliveira Junior, C.A.; Diniz, A.N.; de Araújo Nunes, T.A.; Lobato, F.C.F. Isolation of Clostridium perfringens and Clostridioides difficile in diarrheic and nondiarrheic cats. Anaerobe 2020, 62, 102164. [CrossRef] [PubMed]

18. Hussain, I.; Sharma, R.K.; Borah, P.; Rajkhowa, S.; Hussain, I.; Barkalita, L.M.; Hasin, D.; Choudhury, M.; Rupnik, M.; Deka, N.K.; et al. Isolation and characterization of Clostridium difficile from pet dogs in Assam, India. Anaerobe 2015, 36, 9-13. [CrossRef] [PubMed]

19. Voth, D.E.; Ballard, J.D. Clostridium difficile toxins: Mechanism of action and role in disease. Clin. Microbiol Rev. 2005, 18, $247-263$. [CrossRef]

20. Carter, G.P.; Rood, J.I.; Lyras, D. The role of toxin A and toxin B in Clostridium difficile-associated disease: Past and present perspectives. Gut Microbes 2010, 1, 58-64. [CrossRef] 
21. Gülke, I.; Pfeifer, G.; Liese, J.; Fritz, M.; Hofmann, F.; Aktories, K.; Barth, H. Characterization of the enzymatic component of the ADP-ribosyltransferase toxin CDTa from Clostridium difficile. Infect. Immun. 2001, 69, 6004-6011. [CrossRef] [PubMed]

22. Samie, A.; Obi, C.L.; Franasiak, J.; Archbald-Pannone, L.; Bessong, P.O.; Alcantara-Warren, C.; Guerrant, R.L. PCR detection of Clostridium difficile triose phosphate isomerase (tpi), toxin A $(t c d A)$, toxin B $(t c d B)$, binary toxin $(c d t A, c d t B)$, and $t c d C$ genes in Vhembe District, South Africa. Am. J. Trop. Med. Hyg. 2008, 78, 577-585. [CrossRef] [PubMed]

23. Álvarez-Pérez, S.; Blanco, J.L.; Harmanus, C.; Kuijper, E.J.; García, M.E. Prevalence and characteristics of Clostridium perfringens and Clostridium difficile in dogs and cats attended in diverse veterinary clinics from the Madrid region. Anaerobe 2017, 48, 47-55. [CrossRef]

24. Fathy, M.; Abdel-Moein, K.A.; Osman, W.A.; Erfan, M.A.; Prince, A.; Hafez, A.A.; Mahmoud, H.E.; Mosallam, T.E.; Samir, A. Performance of different laboratory methods for detection of clostridium difficile in animal samples. Adv. Anim. Vet. Sci. 2021, 9, 132-136.

25. Wongwanich, S.; Rugdeekha, S.; Pongpech, P.; Dhiraputra, C. Detection of Clostridium difficile toxin A and B genes from stool samples of Thai diarrheal patients by polymerase chain reaction technique. J. Med. Assoc. Thai. 2003, 86, 970-975. [PubMed]

26. Zhang, T.; Lin, Q.Y.; Fei, J.X.; Zhang, Y.; Lin, M.Y.; Jiang, S.H.; Wang, P.; Chen, Y. Clostridium Difficile Infection Worsen Outcome of Hospitalized Patients with Inflammatory Bowel Disease. Sci. Rep. 2016, 6, 29791. [CrossRef]

27. Cohen, S.H.; Tang, Y.J.; Silva, J., Jr. Analysis of the pathogenicity locus in Clostridium difficile strains. J. Infect. Dis. 2000, 181, 659-663. [CrossRef]

28. Stubbs, S.; Rupnik, M.; Gibert, M.; Brazier, J.; Duerden, B.; Popoff, M. Production of actin-specific ADP-ribosyltransferase (binary toxin) by strains of Clostridium difficile. FEMS Microbiol. Lett. 2000, 186, 307-312. [CrossRef]

29. Abdel-Moein, K.A.; El-Hariri, M.; Samir, A. Methicillin-resistant Staphylococcus aureus: An emerging pathogen of pets in Egypt with a public health burden. Transbound. Emerg. Dis. 2012, 59, 331-335. [CrossRef]

30. Abdel-Moein, K.A.; Samir, A. Occurrence of extended spectrum $\beta$-lactamase-producing Enterobacteriaceae among pet dogs and cats: An emerging public health threat outside health care facilities. Am. J. Infect. Control 2014, 42, 796-798. [CrossRef] [PubMed]

31. Koene, M.G.; Mevius, D.; Wagenaar, J.A.; Harmanus, C.; Hensgens, M.P.; Meetsma, A.M.; Putirulan, F.F.; van Bergen, M.A.; Kuijper, E.J. Clostridium difficile in Dutch animals: Their presence, characteristics and similarities with human isolates. Clin. Microbiol. Infect. 2012, 18, 778-784. [CrossRef] [PubMed]

32. Gumerlock, P.H.; Tang, Y.J.; Meyers, F.J.; Silva, J., Jr. Use of the polymerase chain reaction for the specific and direct detection of Clostridium difficile in human feces. Rev. Infect. Dis. 1991, 13, 1053-1060. [CrossRef]

33. Ghavidel, M.; Salari Sedigh, H.; Razmyar, J. Isolation of Clostridium difficile and molecular detection of binary and A/B toxins in faeces of dogs. Iran J. Vet. Res. 2016, 17, 273-276.

34. Silva, R.O.; Santos, R.L.; Pires, P.S.; Pereira, L.C.; Pereira, S.T.; Duarte, M.C.; de Assis, R.A.; Lobato, F.C. Detection of toxins A/B and isolation of Clostridium difficile and Clostridium perfringens from dogs in Minas Gerais, Brazil. Braz. J. Microbiol. 2013, 44, 133-137. [CrossRef] [PubMed]

35. Drudy, D.; Fanning, S.; Kyne, L. Toxin A-negative, toxin B-positive Clostridium difficile. Int. J. Infect. Dis. 2007, 11, 5-10. [CrossRef]

36. Jalali, M.; Khorvash, F.; Warriner, K.; Weese, J.S. Clostridium difficile infection in an Iranian hospital. BMC Res. Notes 2012, 5, 159. [CrossRef] [PubMed]

37. Janezic, S.; Marín, M.; Martín, A.; Rupnik, M. A new type of toxin A-negative, toxin B-positive Clostridium difficile strain lacking a complete tcdA gene. J. Clin. Microbiol. 2015, 53, 692-695. [CrossRef] [PubMed]

38. al-Barrak, A.; Embil, J.; Dyck, B.; Olekson, K.; Nicoll, D.; Alfa, M.; Kabani, A. An outbreak of toxin A negative, toxin B positive Clostridium difficile-associated diarrhea in a Canadian tertiary-care hospital. Can. Commun. Dis. Rep. 1999, 25, 65-69. [PubMed]

39. Kuijper, E.J.; de Weerdt, J.; Kato, H.; Kato, N.; van Dam, A.P.; van der Vorm, E.R.; Weel, J.; van Rheenen, C.; Dankert, J. Nosocomial outbreak of Clostridium difficile-associated diarrhoea due to a clindamycin-resistant enterotoxin A-negative strain. Eur. J. Clin. Microbiol. Infect. Dis. 2001, 20, 528-534. [CrossRef]

40. Sato, H.; Kato, H.; Koiwai, K.; Sakai, C. [A nosocomial outbreak of diarrhea caused by toxin A-negative, toxin B-positive Clostridium difficile in a cancer center hospital]. Kansenshogaku Zasshi 2004, 78, 312-319. [CrossRef]

41. Drudy, D.; Harnedy, N.; Fanning, S.; O’Mahony, R.; Kyne, L. Isolation and characterization of toxin A-negative, toxin B-positive Clostridium difficile in Dublin, Ireland. Clin. Microbiol. Infect. 2007, 13, 298-304. [CrossRef] [PubMed]

42. Rezazadeh Zarandi, E.; Mansouri, S.; Nakhaee, N.; Sarafzadeh, F.; Iranmanesh, Z.; Moradi, M. Frequency of antibiotic associated diarrhea caused by Clostridium difficile among hospitalized patients in intensive care unit, Kerman, Iran. Gastroenterol. Hepatol. Bed. Bench. 2017, 10, 229-234. [PubMed]

43. Diniz, A.N.; Coura, F.M.; Rupnik, M.; Adams, V.; Stent, T.L.; Rood, J.I.; de Oliveira, C.A., Jr.; Lobato, F.C.F.; Silva, R.O.S. The incidence of Clostridioides difficile and Clostridium perfringens netF-positive strains in diarrheic dogs. Anaerobe 2018, 49, 58-62. [CrossRef] [PubMed] 